\title{
白板紙マシンへの光学式キャリパー計導入事例*1
}

\section{Application of the Optical Caliper Sensor to a White Coated Board Machine}

\author{
王子板紙株式会社*2 富士工場 \\ 清水博文*3 \\ Hirofumi Shimizu*3 \\ Fuji Mill, Oji Paperboard Co., Ltd. ${ }^{* 2}$
}

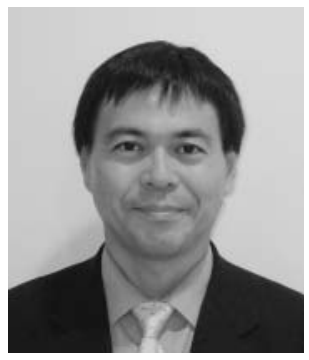

\begin{abstract}
Oji Paperboard, Fuji Mill N 2 machine has produced white coated board since October 2001.

We had the problem with the streaks and sheet breaks by conventional contacting calipaer sensor. Recently, QCS makers have released the online paper thickness measuring equipment which is applied the optical principle to. Then we installed the optical caliper sensor which is produced by Yokogawa Electric Corp. in N 2 for the purpose of reducing the streaks and sheet breaks.
\end{abstract}

分類 $: \mathrm{V}_{3}$ 紙パルプ工程計器およびセンサ, $\mathrm{S}_{12}$ 白板紙（マニラボール・白ボール）

\section{1. はじめに}

王子板紙富士工場第一工場は，1908 年富士製紙株式会 社第八工場として操業を開始, 1996 年には王子製紙株式 会社となり一部品種を除き古紙配合率 $100 \%$ の白板紙と印 刷用紙の生産を展開してきた。生産体制再構築により，本 年 10 月からは近隣の王子板紙株式会社富士工場と一体運 営を目的として王子板紙株式会社富士工場第一工場となっ た。

N 2 マシンは古紙配合両面塗工カード，特板，コート白 ボールを抄造するマシンとして 2001 年 10 月より営業運転 を開始，2010 年 7 月に, 既設接触式キャリパー計による 筋発生及び引っ掛かり断紙を削減することを目的として光 学式キャリパー計を導入した。本報ではその調整概要およ び導入効果について報告する。

\footnotetext{
${ }^{* 1}$ 平成 23 年度年次大会講演（講演 No. E 12 )

${ }^{* 2}$ \% 416-8656 静岡県富士市平垣 300 番地/300 Heigaki,

Fuji-shi, Shizuoka 416-8656, Japan

${ }^{* 3} \mathrm{E}-$ mail : hirofumi-shimizu@opb.ojipaper.co.jp
}

\section{2. 設 備 概 要}

・ワイヤー形式：長網 5 層式

・ワイヤー幅：4,700 mm

・米坪 : $160 \sim 450 \mathrm{~g} / \mathrm{m}^{2}$

- 日産 : $650 \mathrm{t} / \mathrm{D}$

・最高抄速 : $800 \mathrm{~m} / \mathrm{min}$

• $\mathrm{BM}$ 計フレーム数 : 6 フレーム（横河電機製） キャリパー計搭載フレーム‥\#2 (塗工前)，＃6（リー ル前)

3. 光学式キャリパー計導入

\section{1 導入目的}

$\mathrm{N} 2$ マシンでは, BM 計＃2 フレームで目玉欠点や耳カー ルに接触式キャリパ計（以下 GT 計）が引っ掛かることに よる断紙，また\#6フレームでは圧接痕が筋状となり損紙 が発生し，品質及び操業ロスが問題となっていた。そこで これら問題の解決を図るため, N 2 マシンの BM 計メー カーである横河電機株式会社の光学式キャリパー計（以下 OC 計）を＃2・6フレームに導入することとした。

3.2 測定原理

OC 計は上下ヘッド間の距離が磁気センサーにより測定 


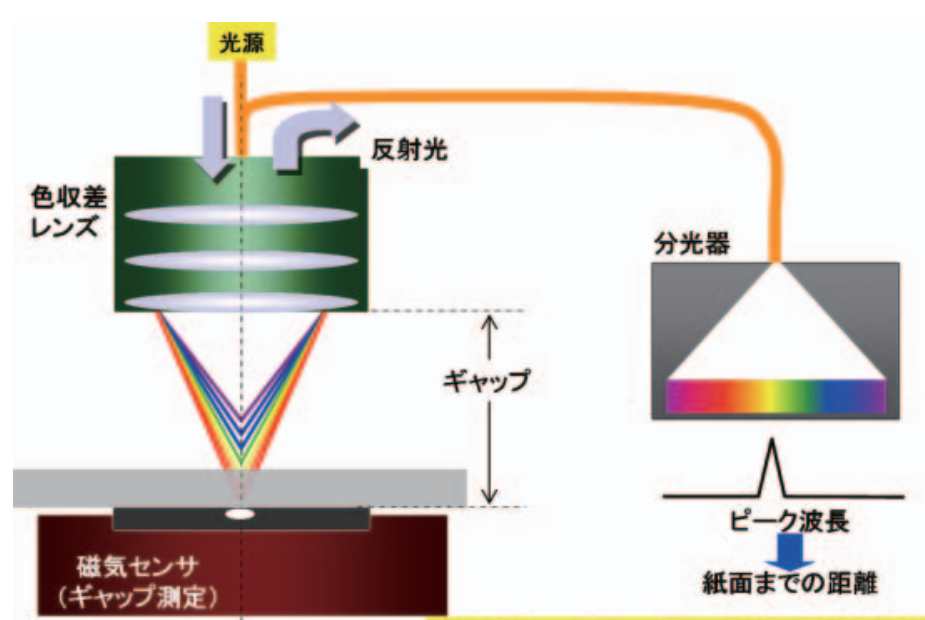

紙厚 $=「 キ ゙ ャ ッ フ ゚ 」 ー 「$ 紙面までの距離」

図 1 測定原理

され, 光学モジュールのあるへッドと紙面との距離は共焦 点技術を応用し, 紙面で焦点距離が合う波長ピークを距離 情報に変換，その差分を紙厚としている。なお安定測定の ため紙裏面のみ紙と吸着接触しているが, 接触面は平滑素 材に鏡面処理したものを使用しており，紙への傷入り等の 影響を最小限にしている（図 1)。

\section{3 吸着圧調整}

OC 計は図 2 のように, 紙面と吸着接触する側は二重リ ング構造となっており, 内周, 外周それぞれで吸着圧を調 整する構造となっている。そこでこの吸着圧を品種・米坪 の違いがあっても以下の条件を満たすように調整した。

・紙面に傷入りがない

・測定值が安定している

・接触面の污れが少ない

約 1 ケ月間全銘柄について調整・確認を行い,

・紙面に傷入りがない $\cdots 0 \sim 2.0 \mathrm{kPa}$ の範囲で調整した 結果では傷入りなし

・測定值が安定している…内・外周圧とも低く（約 0.5 $\mathrm{kPa}$ 以下）なると測定值が不安定

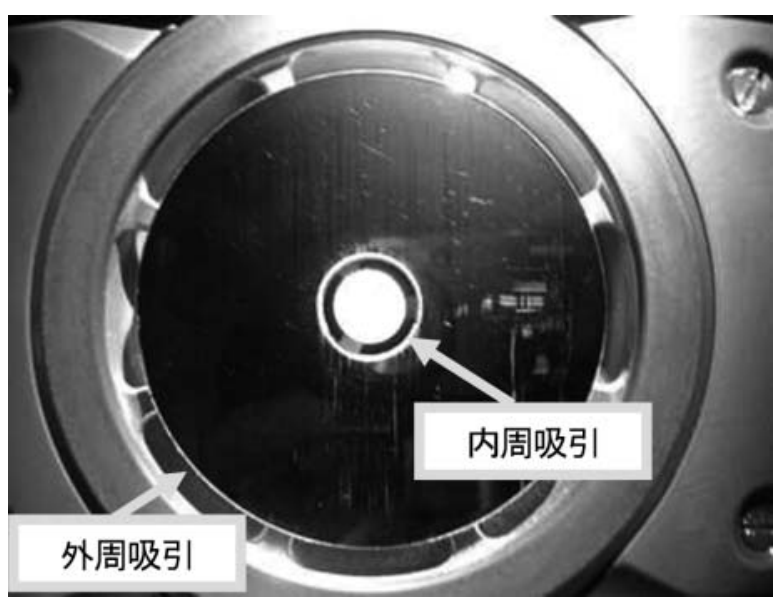

図 $2 \mathrm{OC}$ 計接触面

・接触面の污れが少ない...吸着圧が高いほど污れが付着 しにくい傾向

以上の結果を総合的に判断し以下のように吸着圧を決定 した。

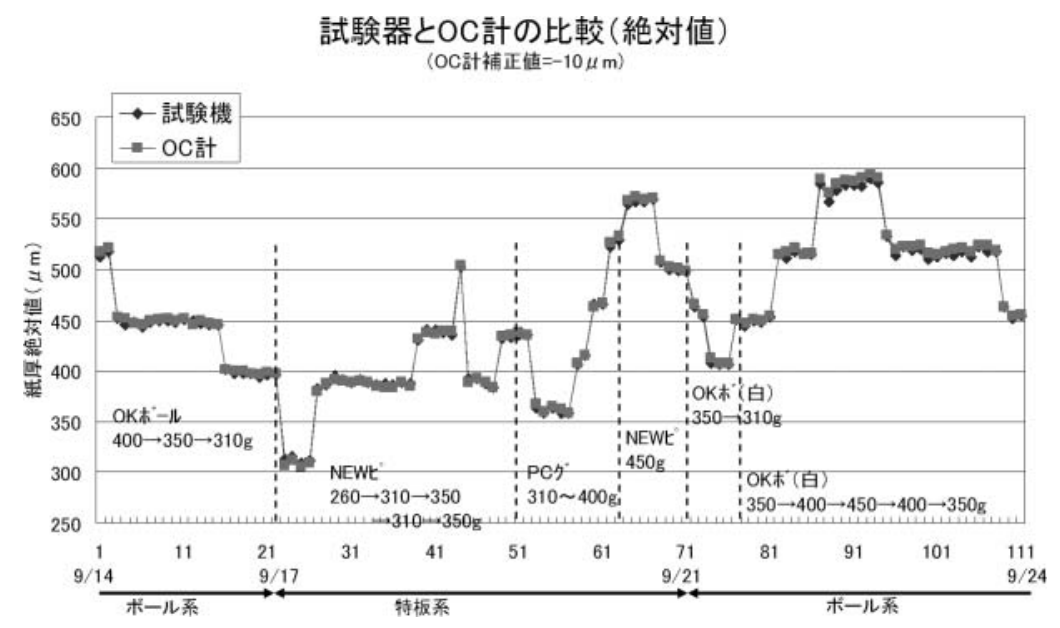

図 3 OC 計一試験機絶対值比較 


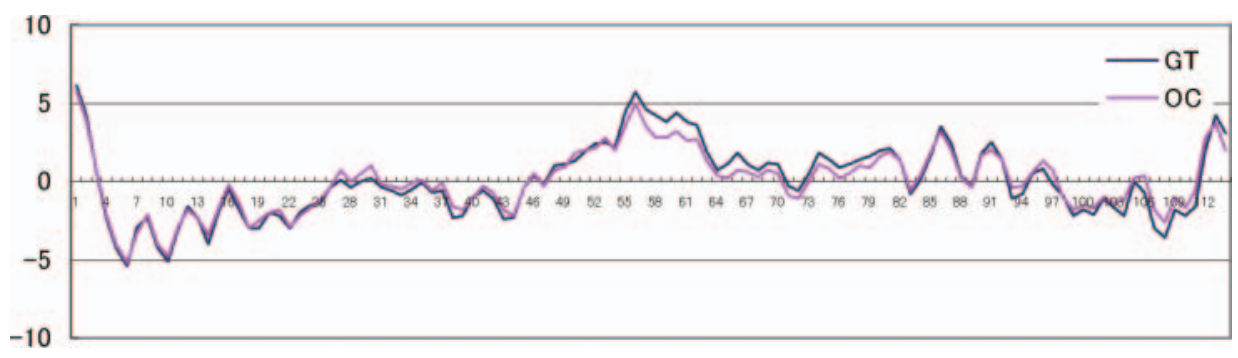

図 $4 \mathrm{OC}$ 計一GT 計プロファイル比較（＃2フレーム）

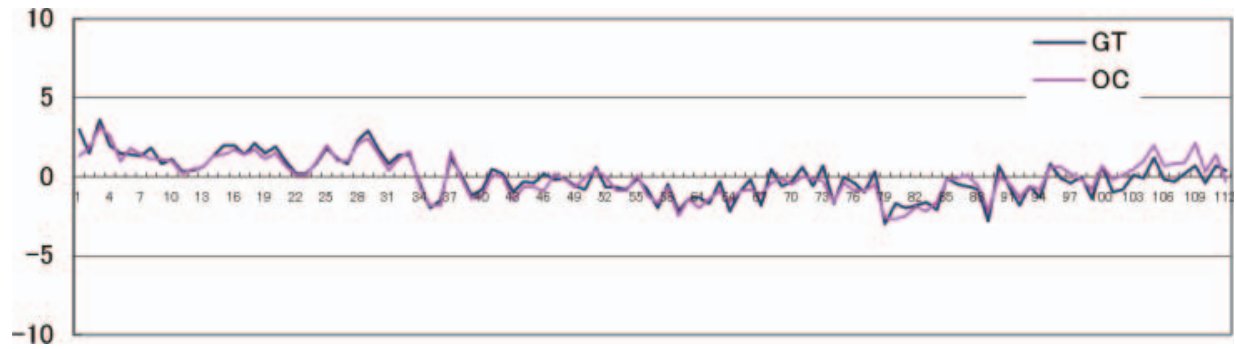

図 $5 \mathrm{OC}$ 計一 $\mathrm{GT}$ 計プロファイル比較（＃６フレーム）

\# 2 フレーム…内周圧：1.2 kPa 外周圧： $1.5 \mathrm{kPa}$ \# 6 フレーム $\cdots$ 内周圧 : $1.2 \mathrm{kPa}$ 外周圧 : $2.0 \mathrm{kPa}$

$3.4 \mathrm{OC}$ 計一試験機絶対値比較

\#6フレーム OC 計測定值と紙厚試験機（autoline 300） の比較を図 3 に示す。

このように銘柄，米坪が変わっても安定した測定を行っ ていることが分かる。偏差はほぼ $\pm 5 \mu \mathrm{m}$ 以内の誤差に収 まっている。なお OC 計測定生值に対して全銘柄でー 10 $\mu \mathrm{m}$ の補正（offset）をかけている。

3.5 測定值 $\mathrm{OC}$ 計一 $\mathrm{GT}$ 計プロファイル比較

\#2, 6 フレーム OC 計と GT 計とのプロファイル比較 を図 4, 5 に示す。

このように GT 計とのプロファイル比較において相関が 高い。なお GT 計接触圧は紙面への筋入り懸念から通常よ りも低く調整していた。1 ケ月間の $2 \sigma$ についても銘柄・ 米坪毎に比較したが，ほぼ同等の結果が得られた。

3.6 接触面の污れ

接触面の污れ具合を図 6，7，8，9 に示す。

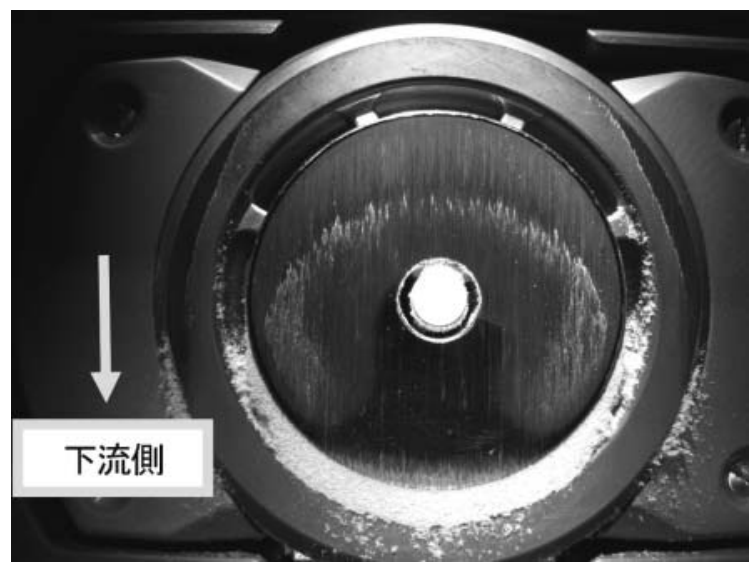

図 6 ボール系，清掃 8 時間後（\#2フレーム）

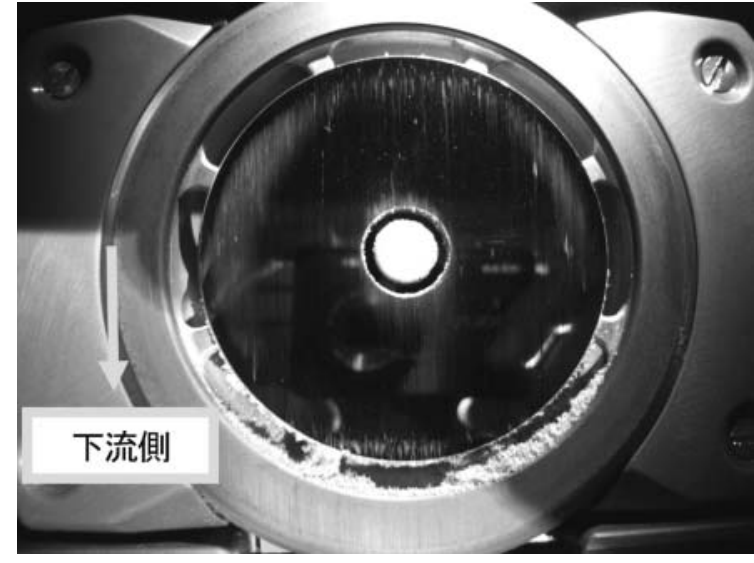

図 7 ボール系，清掃 8 時間後（＃6フレーム）

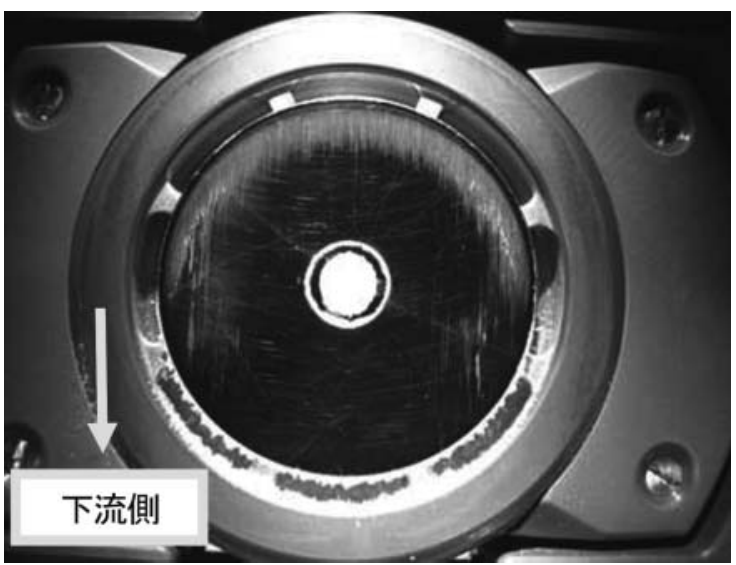

図 8 特板系，清掃 46 時間後（\#2フレーム）

OC 計は紙面と吸着接触しているため，擦れることによ り発生した紙粉が，外周リング下流側に溜まっていること が分かる。紙粉堆積量が多くなると測定值へ影響する恐れ 


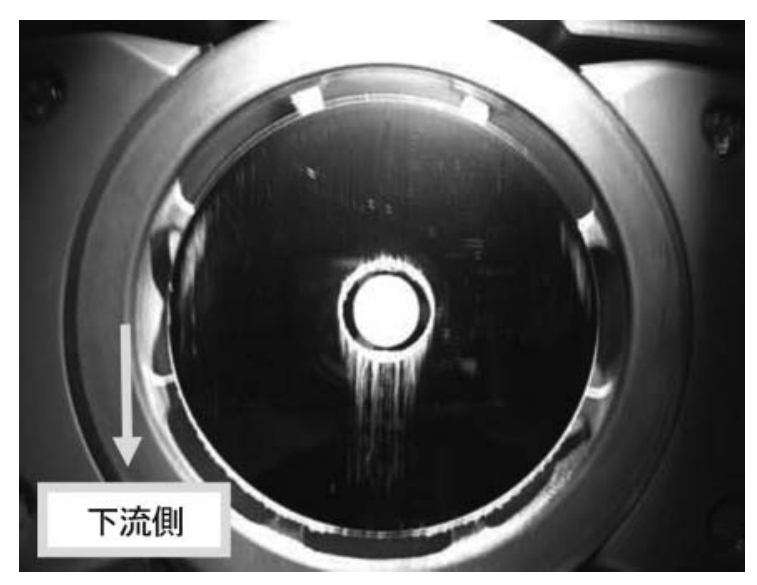

図 9 特板系，清掃 46 時間後（＃6 フレーム）

があるため, GT 計のときと同様, オペレータが定期的に 紙粉除去を行っている。

\section{4. 導入効果}

N 2 の 1 ケ月間生産量構成は, 現状ボール系 $70 \%$, 特板
系 $30 \%$ であり, 当初, 紙表面が接触しない OC 計ではボー ル系での筋入り損抄はなくなることが期待された。結果と しては 2009 年度実績で筋入り損抄が約 200 t, また目玉欠 点や耳カールへの引っ掛かり断紙が 9 回あったが, OC 計 導入 1 年以上が経過した現在まで全銘柄・米坪において筋 入り損抄及び引っ掛かり断紙は 1 度も発生していない。

5. ま と め

$\mathrm{OC}$ 計設置後約 1 ケ月間位置調整など各種調整を行い, その後吸着圧調整，GT 計と併用しての 24 時間連続測定 を経て, OC 計設置約 2 ヶ月後には GT 計を切り離し OC 計単独での運用を開始した。1 年以上経過した現在まで安 定した測定を継続し，接触式キャリパ計起因の損抄・断紙 削減に大きな効果が得られた。また保守面については，保 守部門において月に 1 回測定面の目視確認および吸着圧の 数值確認を行っており, 一度接触面に小さなひびが見つか り交換したが，測定值また紙面への影響はなく，その他卜 ラブルは発生していない。

最後に, 導入・調整にご尽力いただいた横河電機(侏)の 方々をはじめ関係各位の皆様に心より感謝の意を表します。 